\title{
João Nuno Pinto: "As pessoas esquecem-se que so- mos nós que criamos a identidade de um país para as futuras memórias, sem nós é o vazio"
}

João Nuno Pinto: "People forget that it is we who create the identity of a country for future memories, without us is the emptiness"

Paula Lopes - Universidade Autónoma de Lisboa CECS-UMinho NIP-C@M plopes@autonoma.pt https://doi.org/10.26619/978-989-9002-14-2.15

Como citar este capítulo / How to quote this chapter:

Lopes, P. (2021). “João Nuno Pinto: 'As pessoas esquecem-se que somos nós que criamos a identidade de um país para as futuras memórias, sem nós é o vazio'“. In Lourenço, J. \& Lopes, P. (eds.), Comunicação, Cultura e Jornalismo Cultural. Lisboa: NIP-C@M \& UAL, (pp. 289-320), disponível em https:// repositorio.ual.pt/handle/11144/4763 DOI https://doi.org/10.26619/978989-9002-14-2.15

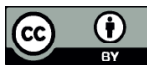


Nasceu em Lourenço Marques, Moçambique, em 1969, filho de uma família de colonizadores. Pragmático e assertivo, não teme as palavras e a brutalidade que, por vezes, lhes imprime: retornado, racista, machista, psicopata. Ao mesmo tempo, descobrimos um homem sereno que se assume como contador de histórias fortes, histórias que tocam as pessoas, que as emocionam, que as fazem pensar. João Nuno Pinto, cineasta e realizador publicitário, outsider sem vergonha, partilha momentos da sua vida numa viagem intimista e autorreflexiva, que começa, naturalmente, em África.

Conhecemo-nos à janela, no auge da clausura pandémica, no dia 12 de abril de 2020. "Estava a ver que nunca mais aparecia ninguém desse lado", disse-me ele, enquanto eu brincava com a minha filha naquela tarde ensolarada. Queria falar sobre teIhados, chuvadas, assuntos menores, mas inadiáveis. Falámos de prédios, de construções, de condomínios. No final, trocámos nomes e números de telefone e foi aí que descobri que o vizinho do prédio ao lado era o João Nuno Pinto.

Já tinha ouvido falar nele e no Mosquito, a sua segunda longa-metragem, obra inspirada na história do seu avô que abriu a competição oficial do Festival de Roterdão. Curiosa, vi o filme, espantei-me e estarreci. Voltei a contactá-lo. Dia 7 de maio, o repto: "João, e que tal uma entrevista?". Aquele "sim" foi o início de um mergulho intenso. Vi os spots publicitários, li as entrevistas disponíveis, mas sentia que ainda havia tanto, mas tanto por 
saber. Mais do que os prémios, as participações em festivais, interessava-me conhecer o homem e a sua singularidade, o João.

A entrevista aconteceu alguns meses mais tarde, eu em Lisboa, no conforto da minha sala, o João no Alentejo profundo, entre chaparros e ovelhas perdidas, no interior de um automóvel ou na "casinha de ferramentas". Falou-me da família, do regresso de África e do regresso a África, de publicidade e de cinema. E do Brasil, de um Brasil que, hoje, é para ele uma triangulação de nomes próprios: Fernanda, Sebastião e Rosa.

Assumindo, à partida, que o ato cultural é indissociável do seu autor, do seu passado, do seu presente, da forma como se sente e se vê, da forma como sente e vê o Mundo, das suas opções e das suas contradições, esta conversa parte do que há de mais umbilical para culminar, finalmente, na cultura em Portugal e no jornalismo cultural.

Na sua página pessoal, o João apresenta-se de forma algo singular: “Pai. Marido." e, só depois, "Fotógrafo amador. Realizador." Diria que há aqui alguma originalidade ou, quem sabe, uma espécie de 'ajuste de contas' com o passado, com a família ancestral...

É sempre uma dificuldade falarmos de nós próprios... Como resumir numa apresentação quem somos? Somos muita coisa, temos muitas dimensões e, realmente, se calhar, antes do Sebastião e da Rosa terem nascido, começava por dizer que era realizador, definia-me pela minha profissão. De facto, a profis- 
são seria o lugar que mais me completaria, mas a partir do momento em que fui pai, a minha vida ficou virada do avesso. Há este conflito: qual o lugar que ocupa a paternidade e o lugar que ocupa o nosso lado profissional? É muito difícil ser um bom pai e um bom profissional. Quando somos uma coisa, a outra fica sempre um pouco em segundo plano. Principalmente nos primeiros anos, na primeira infância, quando eles exigem e dependem muito de nós, e não só eles como a nossa companheira, a mãe. Se não estivermos lá, vai sobrar para ela...

Esta apresentação pública decorre exclusivamente da paternidade, portanto.

Sim, nunca começaria uma apresentação como "amante", se não tivesse sido pai. Neste momento, coloco a família em primeiro lugar, acima de tudo. Eu sempre quis ser pai, ter uma família, e fui pai muito tarde. Sabia que a partir desse momento, ia querer dar muito à família e ia pôr de lado outras coisas que também queria fazer. Então, fui fazendo essas outras coisas e agora estou muito mais apaziguado, por poder dedicar o meu tempo à minha família. Andamos sempre neste dilema, mas se tiver de me definir vou pôr sempre a minha mulher e os meus filhos em primeiro lugar em relação a todas as outras coisas.

Regresso ao 'ajuste de contas'. Essa necessidade de pôr a família em primeiro lugar tem alguma relação com o seu pai?

Sim, sim. Funcionamos sempre em conflito ou em continuidade com os nossos pais. Eles guiam-nos e nós continuamos o que nos deram ou tentamos fazer o oposto. Tenho memórias de in- 
fância e de família muito boas. Mas também tenho consciência que quero ser muito mais do que aquilo que recebi enquanto filho. De qualquer forma, acho que todos os pais fazem o meIhor que sabem pelos filhos e não posso criticar. Eles fizeram o melhor que sabiam. À luz de hoje, temos consciência de que podemos ser muito melhores. Mas não queria pôr isto como uma crítica em relação a um pai que foi ausente em algumas coisas ou que não foi noutras. Não quero mesmo. Sem dúvida que os meus pais vêm de um lugar machista, muito de acordo com a sua época. É um lugar conservador. Achavam-se muito progressistas, mas não eram nada. Aparentemente, tinham um discurso muito democrático e muito progressista, mas não eram nada disso. Esse lugar em que o homem é o grande provedor, aquele que tem as rédeas de tudo, não é? Eu venho desse lugar, essa era a educação lá em casa. Felizmente, sou o mais novo de quatro irmãos e a minha irmã, a mais velha, tem mais sete anos do que eu. A minha educação baseou-se muito nas orientações dessa minha irmã. Ela foi quase a figura materna de referência e, sim, eu seguia-a muito mais a ela do que aos ensinamentos dos meus pais. Claro que, quando somos crianças, achava que o meu pai era incrível, um "super pai". Depois, vem a desilusão da adolescência e da juventude, o choque com a realidade e, depois, o momento do apaziguamento e de voltar a encaixar tudo no seu lugar. Mas acho que o que sou hoje vem, primeiro, dos ensinamentos da minha irmã, que me tornou sempre muito mais ligado ao olhar feminino, e depois, aos poucos, ao longo do meu crescimento e da minha vida adulta há uma tomada de consciência desse lugar que o meu pai representava, do clássico homem branco, machista, autoritário. A soberba do homem branco. 
Essa "soberba do homem branco", como disse, tinha a ver com algum alinhamento com o regime?

Não, o meu pai era socialista, do Partido Socialista de Mário Soares. Era admirador de Mário Soares. Mas, mesmo socialista, ao mesmo tempo, sempre houve - mas isso não é dele em particular, é da família do lado do meu avô - uma soberba, uma altivez, um orgulho de superioridade. As próprias irmãs eram iguais, acho que isso tem a ver com a época. Com a época e as circunstâncias...

O João nasceu em Moçambique, o seu pai nasceu em Moçambique, já que o seu avô regressou a África depois da I Guerra Mundial e aí teve sete filhos...

Sim, sete filhos da minha avó Virgínia. O meu avô paterno sempre foi colocado nesse lugar do patriarca, do aventureiro, quase um Dom Quixote, mas com o coração no lugar certo, uma "criança grande" que gosta de experimentar novos caminhos e novas aventuras. A minha avó era o lado sólido da família, segurava as suas aventuras e as suas paixões...

"Vivíamos o sonho de uma herança colonial, uma ressaca, um ranço de um colonialismo que foi transportado para dentro de casa"

Depois, em 1975, há o regresso de África. O João vem de Moçambique para Lisboa com cinco anos.

Sim. Quando vim de África, continuámos a viver África durante muitos anos, imagino que como todos os retornados. Toda a 
gente que veio de África trouxe África no coração, só que trouxe uma "certa" África. Lá tínhamos uma vida incrível, vivíamos quase o american dream. Aquela imagem que temos dos anos 50 americanos era o que vivíamos em África. Tínhamos uma casa maravilhosa, tínhamos empregados, barcos, viagens... Nos álbuns e álbuns de fotografias, parece que vivíamos férias eternas... os safaris, as grandes almoçaradas e as grandes jantaradas, sempre rodeados de amigos. Quando os meus pais vêm para Lisboa, o meu pai fica completamente deprimido, passa a ser outra pessoa. Esses encontros... isso acaba tudo. Há um isolamento, mesmo em relação à família mais alargada. Passa a haver um isolamento muito grande, imagino que também pelas dificuldades. Recomeçar tudo com 40 anos e, depois de tudo ter, tudo perder. Recomeçar a vida com quatro filhos não deve ser nada fácil. Imagino que para eles foi difícil. Lembro-me perfeitamente de ser jovem e não termos nada... de quatro irmãos a dividirmos uma romã. Não tinha roupa nova, usava a roupa dos meus irmãos. Passámos de um lugar onde tínhamos tudo para um lugar, que era o Portugal do final dos anos 70 e anos 80 , que era... [pausa] Bom, vivíamos com bastantes dificuldades. Isso para os meus pais não foi nada fácil. Mas sempre alimentaram o sonho que África é que era, aqueles tempos é que eram...

\section{E voltaram a Moçambique?}

O meu pai voltou. Na verdade, todos nós voltámos, acabámos por voltar a Moçambique. O que há depois desse regresso é, realmente, e em particular da minha parte, a tomada de consciência de que imaginário é esse, qual era a nossa herança, o 
que se passava de facto. Nós, de facto, vivíamos o sonho de uma herança colonial, uma ressaca, um ranço de um colonialismo que foi transportado para dentro de casa. E como isso nos influenciou, a nós e a um País inteiro! Nós continuamos a viver nesse ranço dessa colonização e desse império perdido. E como é que nos desligamos e percebemos como é, de facto, a realidade? Como é que lidamos com isso? É quando surgem todas as grandes questões...

Suponho que essa mudança pessoal, interior, se dê quando o João começa a olhar para essa realidade de uma outra forma, mais crítica e reflexiva. Hoje, e pelo que vejo nos spots publicitários e nos filmes que realiza, é um homem centrado nas relações humanas, com uma visão humanista, provavelmente em confronto com todo esse percurso. Recordo-me de alguns vídeos marcados por narrativas visuais elegantes, textos intensos, personagens frequentemente fortes. Diria que há traços comuns que os unem: emoções, relações...

Eu e os meus irmãos fomos criados muito em liberdade, sempre tivemos muita autonomia. Quase que éramos largados e tipo: "virem-se!" Uma recordação que tenho de infância é os meus pais deixarem-nos no Algarve durante um mês, numa caravana no parque de campismo, e a minha irmã mais velha, na época com 15 anos - por isso, eu tinha sete ou oito anos - tratava de nós. Ficávamos os quatro sozinhos. Crescemos assim, ora no Algarve, ora em Monsanto, crescemos muito assim: "virem-se!" Não éramos aquela família em que os pais se sentam a fazer os trabalhos de casa com os filhos. Mesmo na escola, era suposto 
termos boas notas, passarmos de ano. Mas era por nós. A exigência estava lá, devíamos cumprir os objetivos, mas o acompanhamento não. Ao mesmo tempo, isso criou coisas muito boas, perceber o grande valor da liberdade, de sermos muito destemidos. Nenhum de nós tem problemas em começar de novo, já sabemos que tanto podemos ter muito, como podemos não ter nada, porque vivemos as duas realidades. Com 16 anos, comecei a viajar à boleia na Europa. Muitos dos meus irmãos já o faziam, mas com 20 e tal anos. Comecei mais cedo, logo com 16. E os meus pais deixavam. Lembro-me de ter poucos amigos com essa liberdade. Consegui arranjar um grupo que alinhava comigo, os pais deixavam... Então, eu venho desse lugar, de um mundo onde não havia amarras e isso fez com que tivesse um percurso invulgar na minha juventude... Sempre me atirei de cabeça a tudo! Sempre me atirei de cabeça, nunca tive problemas em começar seja o que for, viajava e nunca precisei de dinheiro para viajar, ia à boleia para todo o lado. Fiz muitas asneiras, fiz muitas coisas que não devia ter feito, mas havia mesmo aquela necessidade de experimentar tudo...

E a nível profissional, também é assim? Como no copy de uma marca brasileira de cerveja, "Todo o dia é dia de correr atrás de seus sonhos (...) Todo o dia é dia de acreditar"...

Sim. Para já, sempre tive uma "estrelinha" que cuidou de mim e que não deixou que as coisas corressem mal, a todos os níveis. Profissionalmente, sempre desenhei. Desde miúdo, sempre desenhei, sabia muito bem que queria seguir a expressão visual. Os meus cadernos eram "tirinhas" de banda-desenhada, fazia 
histórias aos quadradinhos nos meus cadernos da escola. Era péssimo a Português, odiava Gramática, Matemática... tudo o que me fizesse parar e pensar numa coisa profundamente. Não tinha paciência. Ainda por cima, sou disléxico, perdia-me no pensamento. $E$, no entanto, em tudo o que me fizesse sonhar $e$ viajar era muito bom, adorava. Era o melhor aluno a Desenho, a História de Arte e a Geometria Descritiva. Conseguia visualizar no espaço. Depois, era um aluno medíocre a Matemática, a essas coisas mais concretas. Se não respeitasse o professor, se não admirasse o professor, não ligava nenhuma às aulas dele. No entanto, se tivesse um professor que admirasse e respeitasse, dava tudo por ele. Então, tinha de ser seduzido e levado para esse lugar... Sempre fui esse miúdo que gostava muito da liberdade e de poder fazer o que the dava na gana...

Lá está, o culto da liberdade, a emoção... Exatamente.

\section{"A minha busca sempre foi numa perspetiva do sonho, de um miúdo a tentar perceber o seu lugar no Mundo, a tentar sonhar e encontrar o seu lugar no Mundo"}

E o que fez o miúdo que só fazia o que lhe dava na real gana para começar a tornar-se financeiramente independente?

Comecei a fazer uns trabalhos de design, mas - como era preguiçoso - não me apliquei a sério nos estudos. Queria era viajar e andar na borga, e segui o caminho mais fácil. Fui parar a Tomar, ao politécnico, que estava a fazer o primeiro curso de Artes 
Gráficas. Não gostava nada, odiei aquilo. Depois, pus os meus desenhos debaixo do braço e fui à procura do meu primeiro trabalho. Fui bater à porta de uma agência de publicidade e adoraram os meus "bonecos". Fui contratado pela Abrinício, uma agência que já não existe mas que, na época, era uma agência muito importante em Portugal. Era a marca nacional da J. Walter Thompson, trabalhavam contas portuguesas, como o Azeite Gallo, a Sagres... Eu não fui atrás da publicidade, fui atrás do primeiro trabalho que arranjasse. Comecei a trabalhar lá com 21 anos, fiz um primeiro estágio e, de repente, com 25, passei a ser diretor criativo da agência. Ou seja, em quatro anos, passei de um estagiário, que não entendia nada de publicidade e fazia uns bonecos, a diretor criativo. Começou a acontecer tudo muito depressa, ou seja, os acontecimentos da minha vida iam mais rápidos do que eu próprio conseguia controlar. Foi tudo tão rápido, era um mundo novo, um mundo deslumbrante, a publicidade, o glamour. De repente, era diretor criativo, tinha um projeto que estava nas minhas mãos, tinha um grupo de criativos a trabalhar para mim... Trabalhávamos dia e noite, fazíamos noitadas atrás de noitadas, as coisas estavam a correr muito bem. Com 28 anos, ia fazer parte do conselho consultivo do Grupo Thompson, ou seja, tinha ali um futuro brilhante supostamente à minha espera. Mas o que é certo é que já estava muito insatisfeito, aquilo já não me dizia nada, porque eu só trabalhava... Quando recebi o meu primeiro cheque de ordenado, um bom ordenado, já como diretor criativo, nesse dia, olhei para aquilo e pensei: "Eu já não preciso mais de pensar em dinheiro." E, à partida, nunca mais pensei em dinheiro, ou seja, o dinheiro nunca 
foi aquilo que me moveu para fazer as coisas. Nesse momento, não foi tipo "enfim, vou ficar rico", mas "fixe, não preciso mais de pensar em dinheiro". Antes, precisava de pensar em dinheiro para ganhar a vida, para conseguir pagar as coisas que queria fazer, para viajar. Naquele momento, foi um grande alívio: "Não preciso mais, ganho o suficiente para viver e viver bem! Ótimo, essa parte está resolvida."

\section{E está resolvida, de facto?}

Faço publicidade, é o que me paga as contas, se não fosse a publicidade... felizmente há publicidade! [risos] Mas, de facto, o que é que aconteceu? Com 28 anos, fui fazer um coast to coast nos Estados Unidos e estava em Monument Valley, onde o John Ford filmou os seus westerns, a ver toda aquela paisagem incrivel. Já tinha esta coisa pelo cinema, queria realizar. Estava ali sentado, sozinho, comecei a olhar para a minha vida em Portugal e pensei: "bom, é isto que eu quero, não quero continuar num agência de publicidade a aturar diretores de marketing e contas!" Nada daquilo já me fazia sentido. Pensava: "Quero mesmo é isto, é criar histórias, é contar histórias, é viver este sonho." E, sem preparação nenhuma, sem nada, voltei para Lisboa, fui ter com o meu chefe e despedi-me. Ou seja, só tinha ido de férias e cheguei a Lisboa e despedi-me. Disse a mim próprio: "Nunca mais, eu quero mesmo é realizar!" Pesquisei e havia um curso em Nova lorque, que conseguia pagar com o dinheiro que ainda tinha. Fui para Nova lorque. Fiz lá um curso de três meses, mais uns workshops, voltei e comecei a realizar. Quem me deu trabalho foi, obviamente, a publicidade, foram os criativos que 
tinham trabalhado comigo e me deram os primeiros filmes. A coisa começou a correr bem e assim foi. Mais tarde, fui sócio de uma produtora, depois abri a minha própria produtora e tudo isto sempre a correr profissionalmente muito bem...

Até chegar ao América (2010), a sua primeira longa-metragem. Se não estou em erro, estreou-se na Competição de Longas do IndieLX. Nessa ocasião, o João foi apresentado como "realizador publicitário"...

Ao fim de um tempo, fiz o América, finalmente, depois de muitos anos a tentar financiamento para fazer uma primeira obra. Era, justamente, visto como realizador de publicidade e havia um grande desprezo por parte de todo o círculo do cinema, um círculo muito fechado, a tal intelligentsia do cinema, os intelectuais que não deixam [entrar] quem vem de fora... É logo criado um rótulo e, para mim, era o rótulo de "publicitário". Tipo: "Mas o que faz um publicitário aqui a querer fazer cinema?" Tal como na altura em que deixei a agência para ser realizador, fui dos primeiros a deixar de ser criativo para começar a realizar. Hoje em dia, isso é banal, mas na altura não era uma coisa que em Portugal se fizesse normalmente. Também fui dos primeiros realizadores de publicidade a querer fazer cinema. Em Portugal, porque lá fora isso era uma coisa normalíssima! Tive muita dificuldade em conseguir financiamento, recebi muitas críticas enviesadas ao América. Olhavam-me sempre como um outsider que não era suposto estar a fazer cinema, era suposto estar lá, noutro lugar, a fazer publicidade. Mas eu não vinha da publicidade, vinha de um outro lugar, vinha do lugar do sonho e da cria- 
ção. Passou pela publicidade, a publicidade deu-me uma grande escola em muitas coisas, mas não fui um produto da publicidade, que sonhava e respirava publicidade. A minha busca sempre foi numa perspetiva do sonho, de um miúdo a tentar perceber o seu lugar no Mundo, a tentar sonhar e encontrar o seu lugar no Mundo. Não venho do lado académico do cinema, o meu percurso é muito autodidata nesse sentido, de descoberta. Há um momento neste percurso que fundo a Garage Films, que se torna uma das maiores produtoras de filmes de publicidade em Portugal e há um momento em que estou saturado, um momento em que não aguento mais aquilo outra vez - tal como aconteceu com a agência de publicidade. 0 meu lado criativo estava a ser completamente canibalizado pelas obrigações de ter uma produtora, pelas obrigações de faturar, de ganhar dinheiro e de ser obrigado a fazer filmes atrás de filmes e aturar todo aquele mundo da publicidade. Atenção, adoro fazer filmes de publicidade, mas têm de ser feitos em doses homeopáticas! A publicidade é um excelente exercício para praticar. Por exemplo, se fosse só fazer cinema estava tramado, faço um filme de oito em oito anos, nunca praticava. [risos] A publicidade permite-me praticar, estou a filmar de dois em dois ou mês a mês, permite-me estar sempre a filmar, a praticar, a conhecer. A publicidade é uma escola de cinema constante, a nível técnico. Há novos projetos, novos desafios que nos chegam, que nos pagam a renda e nos fazem ganhar mais experiência. Mas voltando à Garage Films, às tantas, estava com uma grande insatisfação, e um vazio que não percebia bem porquê, mas que coincidiu com a chegada aos 40 anos. Percebi que ainda não era aquilo. Já tinha feito tanta coi- 
sa... até já tinha aberto um clube, não sei se se lembra do Clube Ferroviário...

\section{Muito bem.}

Abri o clube com mais três sócios e foi só por gozo, nunca quis ser empresário da noite. Foi mesmo por brincadeira, ainda andava a tentar ocupar o tempo com coisas que me dessem gozo, com novos desafios... Olhando para trás, para o João de outros tempos, era claramento o meu perfil. Hoje, há um novo desafio, o objetivo mudou: agora vivo em prol da família e não do gozo pessoal. Mas se há uma coisa que gosto no cinema e na profissão que tenho é cada trabalho ser um desafio hermético, tem um princípio, meio e fim. Gosto disso, sou péssimo na gestão... Se me dão uma coisa para ficar a gerir no dia a dia, isso para mim é um pesadelo... Estar ali a fechar contas todos os dias, não consigo, não tenho esse perfil. Agora, essa coisa de desafio, de criar, de pensar como pode ser feito, de montar o projeto, de ver a coisa feita, até ver a coisa terminada, isso para mim é super aliciante. Quando cheguei aos 40 anos - e foi aí que conheci a minha mulher, a Fernanda - o Brasil começou a aparecer muito na minha vida. Por vários motivos. Primeiro, fiz uma publicidade para o Brasil e, de repente, veio uma conta de uma agência brasileira para filmar em Portugal. Adorei a relação com os criativos, com a equipa. $E$, de repente, toda a pós-produção de som do meu filme, o América, foi feita no Brasil. Então, estive um mês a viver em São Paulo. 
"A minha necessidade como storyteller, como contador de histórias, vem desse lugar, de tocar as pessoas, de as emocionar, de as fazer refletir sobre o Mundo em que vivemos"

O América é uma adaptação de Criação do Mundo de Luísa Costa Gomes, argumento no qual o João também participou.

O América é um projeto que parte da Luísa Costa Gomes, sim. Ela tem um primeiro draft do guião, eu leio o guião, gostei muito da história e disse-lhe: "Vamos, ainda há aqui muito para trabaIhar até isto virar um filme!" Sendo que não é uma ideia minha, tenho que, de alguma forma, me apropriar deste filme, para poder falar sobre ele. E então, sentei-me com a Luísa e estivemos a trabalhar em conjunto no guião.

O filme trata de um tema que está na ordem do dia: a imigração ilegal. Quando pensa em cinema, em fazer cinema, pensa intencionalmente em contar histórias que retratem dramas humanos, da Humanidade? Ou seja, pensa em Direitos Humanos e que são essas as histórias que valem a pena contar?

A minha necessidade como storyteller, como contador de histórias, vem desse lugar, de tocar as pessoas, de as emocionar, de as fazer refletir sobre o Mundo em que vivemos. No caso do América, eu "sou" muito do filme porque era um olhar sobre Portugal do ponto de vista dos imigrantes, com que me identifiquei. Embora seja português, o facto de só viver aqui desde os cinco anos e ter nascido em Moçambique, vir de outro lugar e de ter tido esse impacto da mudança, de olhar para Portugal 
como estrangeiro... sempre tive um pouco este olhar exterior a Portugal. Então, identifiquei-me a falar sobre Portugal segundo esse ponto de vista. O filme fala de uma russa que está presa por causa do seu filho e não consegue sair, abandonar o marido, não consegue sair de Portugal e a amargura que ela sente em viver aqui, em estar presa a Portugal. Ele e os outros imigrantres vêm à procura de um eldorado, de uma nova terra de oportunidades, daí o América. Para estes imigrantes, Portugal é um eldorado falhado, cheio de problemas, de questões e o filme retrata o confronto com essas questões. Coincide com uma altura em que eu estava com uma visão muito negativa de Portugal, estava muito farto de aqui estar, tanto mais que, a seguir ao América, eu saio de Portugal. Eu hoje olho para o filme e consigo ver isso claramente. Estava com muita coisa atravessada que tinha a ver, claramente, com a falta de horizontes deste País. Sempre precisei de horizontes e sentia-me aqui a sufocar. E acho que o filme fala disso, fala do que eu estava a sentir na altura. O guião da Luísa era uma coisa mais leve, tornei-o uma coisa mais negra, exatamente com esse ponto de vista.

É casado com uma brasileira, a Fernanda, para todos os efeitos imigrante, que - tal como o João - terá um olhar necessariamente exterior a Portugal. Também ela se sentirá "presa" a este País?

Sou casado não só com uma brasileira: sou casado com uma brasileira, ativista, feminista, que trabalha muito com as questões de género e as questões raciais, que é investigadora, guionista. Acho que uma das razões por que eu me apaixonei por ela foi 
exatamente a nível intelectual. Nós entendemo-nos nesse lugar e atraiu-me esse lugar. A Fernanda tem uma grande responsabilidade na minha consciência acerca de muitos assuntos que têm a ver com esses temas. Eu era uma pessoa que estava à procura e aberta para receber e para evoluir, e, de repente, encontrei uma pessoa que trabalha ativamente nesses temas e que coloca tudo em sentido e dá sentido a muitas coisas que já estavam na minha cabeça. Então, muito devo à Fernanda a minha evolução nos últimos dez anos, dos 40 aos 50 anos... A Fernanda vê Portugal como um país racista, xenófabo, desigual, tudo isso. Completamente. Ela está ainda a processar o facto de ter vindo para cá. O Brasil é um país tão grande, com problemas gigantes, enormes, endémicos, que nunca serão resolvidos, mas depois há um outro lado, um outro Brasil, um país de pessoas incríveis, de intelectuais incríveis, de pensadores incríveis, de ativistas... 0 que ela sente em relação a Portugal é que, mesmo do lado do ativismo, o país ainda está fora de várias discussões que já estão a correr esse Mundo fora. E aqui ainda não se fala nelas. [pausa] Por exemplo, ela fez um filme, escreveu e foi codiretora de um projeto que ganhou um prémio agora, que se chama $O$ que Elas Fazem, que é um filme sobre a questão da igualdade de género e racial no mercado de trabalho. Ganhou até o Prémio de Melhor Curta-Metragem nos Estados Unidos, num festival em Los Angeles. Ela quer fazer o mesmo projeto aqui em Portugal e estava a comentar, outro dia, que estava muito admirada de ter estado a ler sobre o assunto, a fazer pesquisa, e de ter percebido como a questão racial não entra na equação cá em Portugal. Em toda a discussão da igualdade de género no mercado 
de trabalho em Portugal, dos direitos das mulheres, a questão racial nunca é colocada. E ela pergunta: “Como é possível?" Não há só uma questão de género, há uma questão educacional, há, de facto, uma grande desigualdade entre o homem e a mulher, mas quando vamos analisar a mulher negra o fosso ainda é muito maior. Não se pode abordar uma coisa sem falar na outra. É nisto que ela fala, que esta discussão ainda está muito atrasada, e diz que Portugal ainda é um país muito conservador para trabalhar estas temáticas.

\section{A Fernanda é também argumentista do Mosquito...}

Sim, a Fernanda é argumentista do Mosquito. O Mosquito é um filme que eu queria fazer, uma história que eu queria contar, ainda antes de ter filmado o América. Só que não me sentia preparado para o fazer, porque é um filme muito mais ambicioso e muito mais sensível. Quando termino o América, então digo, "OK, então agora vou começar a trabalhar no Mosquito". E começo a trabalhar com a Fernanda, começamos os dois a trabaIhar. É engraçado que, quando conheço a Fernanda, ela não era guionista. Ela é socióloga, sempre trabalhou em organizações não governamentais, em ONGs, com questões africanas, com questões da cultura africana no Brasil. Depois de nos conhecermos, começa a entrar no mercado audiovisual, primeiro como investigadora, depois como guionista e agora também como realizadora, mas sempre no lado documental, sempre com este olhar, este viés social, temas sociais. O Mosquito foi também uma primeira viagem para ela na ficção. 
E deve ter sido uma viagem alucinante, porque era uma viagem que partia de si... 0 Mosquito estreia 10 anos depois de América, sendo um filme inspirado na história do seu avô. $\mathrm{E}$, tal como aconteceu com o América, o filme estreia-se sete ou oito anos depois de começar a ser pensado, por constrangimentos financeiros - uma coprodução com Brasil, França, Moçambique, com produção de Paulo Branco - e dois meses de rodagem em África.

Exacto. Uma viagem que parte de mim e tem de haver do lado da Fernanda uma apropriação do tema para ela se integrar. Esta viagem tem de ser feita sempre da mesma maneira: quem entra, tem se se apropriar, porque se não é impossível, passa a ser só mais um técnico. $\mathrm{E}$, aqui, eu venho com o conhecimento mais técnico da narrativa, do storytelling cinematográfico, ela vem com um lado mais social e com essas questões humanitárias que ela traz para o filme. A visão dela foi estruturante na visão do filme. Chegou um ponto que tínhamos já um argumento do princípio ao fim e precisávamos de trabalhar as cenas e os diálogos, e aí chamámos o Gonçalo Waddington para se juntar à equipa e escrever com ela o guião final. Precisávamos de um olhar masculino e português, porque é um filme muito masculino e português. Muito bélico. $O$ Gonçalo trouxe esse olhar masculino português, com outra coisa que ele tem: uma criatividade maravilhosa para os diálogos e para as cenas. Ele trouxe isso para o filme, foi essa a "poção" para escrever o Mosquito. A cena de abertura diz logo ao que o filme vai. O filme foi-se tornando cada vez mais ambicioso à medida que evoluímos na pesquisa e que íamos pensando como fazer. Começa a ser pensado como uma 
história, que é uma das histórias do meu avô que sempre me fascinou, como já disse. Eu nunca conheci o meu avô, quando nasci ele já tinha falecido há muito tempo, mas sempre se falou muito dele e dessas histórias. E esta história sempre me fascinou: este rapaz, este jovem que vai para Moçambique, que quer muito ir para a guerra, ir para França combater os alemães, mas é enviado para Moçambique, apanha malária e é deixado para trás pelo seu pelotão. Depois, parte à procura da guerra sozinho, com um guia e um carregador, à procura da guerra... Contado assim quase parece a história do Raúl Solnado, de ir à procura da guerra...[risos] é quase como uma anedota! Sempre questionei o que é que aconteceu nesta viagem a este miúdo, que deve ter sido tanto de fascinante como aterradora, para que depois, mesmo assim, ele tivesse querido ficar em Moçambique e tivesse aí a sua família. Este foi o ponto de partida, um ponto de vista, um ponto de partida de aventura, lá atrás, quando comecei a pensar na história. Penso que devo ter começado a pensar neste filme há uns 20 anos...

\section{E o financiamento? Os constrangimentos financeiros?}

Em Portugal, fazer cinema é muito, muito difícil. É preciso ter muitos projetos a andarem ao mesmo tempo, uma pessoa não pode ter só um projeto, tem de ter vários projetos para continuar. E o mais difícil, de facto, porque há pouco dinheiro e muita gente a querer fazer cinema, é que não dá para todos, não há dinheiro para todos. $\mathrm{O}$ dinheiro que há para cada projeto é pouco. No caso do América, tive muita dificuldade porque eu não era ninguém. O América foi uma coprodução, um filme com finan- 
ciamento português, espanhol, russo e brasileiro. Em Portugal, é muito cómico existir um concurso que se chama "Primeiras obras", portanto, para alguém que vai fazer a sua primeira longa-metragem. $O$ facto de eu não ter um percurso óbvio, como não vir da Escola de Cinema, nem ter sido assistente de realização de alguém, ter sido sei lá o quê dentro do cinema, ou seja, ser completamente um outsider dentro deste mundo, fez com que, mesmo para primeiras obras, a minha pontuação do currículo fosse sempre muito fraca. Então, foi muito difícil conseguir o financiamento para fazer o filme, daí tantos anos para conseguir financiamento. No Mosquito, voltei a ter essa dificuldade, continuei com esse rótulo de "realizador de publicidade" que tinha feito um filme há não sei quantos anos... e ouvi coisas ridículas. Eu ficava lá e eles falavam muito bem do argumento, mas ouvia coisas como "é impossível filmar isto" ou "é um guião demasiado esquematizado"... Não sei... falavam muito bem do guião, uma história muito interessante e tal, mas era um guião demasiado esquematizado. Penso que queriam dizer que era demasiado correto, não sei. O guião foi escrito de uma forma cronológica, mas o filme não é editado de uma forma cronológica. Sempre vi, nas minhas pontuações, reduzirem os prémios que o América tinha ganho. Vi todo o meu percurso a ser reduzido para, de facto, a minha pontuação não ser muito alta.

\section{Ou seja, está a assumir que o jogo está viciado.}

O jogo está muito viciado. É muito difícil. E, claro, hoje em dia, a partir do momento em que o filme está feito e abriu Roterdão - foi o primeiro filme português a abrir um festival de Categoria 
A - de repente, o João Nuno já não é um realizador de publicidade, já é um cineasta! [risos] E noto, claramente, a mudança de atitude do pessoal do cinema, dos críticos e dos outros, em relação a mim. Ou seja, a atitude mudou. Mas as portas não estão abertas, é preciso muita persistência e muita carolice, não desistir, provar que sabemos e que somos capazes. O Mosquito teve outro problema: estive três anos para conseguir montar essa engenharia, conseguir esse financiamento e, quando finalmente íamos filmar, quando finalmente estava tudo pronto, já tinha feito as viagens todas a Moçambique e estava tudo preparado, começa a haver ataques em Moçambique entre a Frelimo e a Renamo. Então, a uma semana de embarcarmos, tivemos de cancelar as filmagens. E aí, aconteceu um grande problema: íamos filmar no Norte de Moçambique e o Norte deixou de ser seguro. Tivemos de refazer tudo. Tive de voltar a fazer nova repérage, procurar lugares de filmagem no Sul de Moçambique, novas viagens, alterar o guião. Nos meus filmes, tento sempre que haja uma relação entre o espaço físico e o estado psicológico do personagem, um é sempre uma representação do estado psicológico do outro. O Norte de Moçambique é mais floresta, é mais verde, o Sul de Moçambique é mais savana e, para que uma coisa continuasse a bater certo com a outra, tive de alterar também o guião. $E$ isto foram mais anos. $O$ próprio produtor teve de conseguir arranjar dinheiro outra vez para conseguirmos filmar... Por isso é que demorou tanto tempo... Espero que o próximo não demore tanto. 


\section{"Eu sou fruto da colónia. Eu venho desse lugar, mas eu não sou esse lugar, tenho outra visão do Mundo e é esta a minha visão do Mundo"}

Ao jornal online Observador, afirmou: "O que se passou em África foi outro Holocausto." É uma afirmação corajosa e brutal. Foi um alerta para a necessidade de questionarmos a ideia dos "bons colonizadores" e da leviandade de uma certa "banalização do mal"?

Quando começamos a fazer pesquisa para o filme, várias questões se começam a levantar. Havia muito pouca informação. Começo a deparar-me com uma guerra brutal, uma coisa horrorosa, que tinha sido propositadamente apagada dos livros de História. Tudo o que se passou ali, na guerra, nessa guerra, foi tão humilhante do ponto de vista da raça portuguesa, daquilo que era a doutrina da Ditadura Nacional e do Estado Novo - que veio logo a seguir - e que era a nossa justificação para poder colonizar aquelas terras, a prioridade europeia, a prioridade da raça portuguesa, do homem branco perante os povos primitivos... [pausa] Aquela guerra demonstrou exatamente o oposto e convinha não falar nisso. Por isso, não se ensinava, não se escrevia, nada foi dito sobre isso. Cheguei a deparar-me com o facto de, toda a gente com quem falava, ninguém sabia que Portugal tinha estado na I Guerra Mundial em África, em Moçambique. Portanto, havia a Guerra Colonial e, na I Guerra, havia a Batalha de Flandres, mas não a I Guerra em África. E eu começo a deparar-me com o horror. Ou seja, a partir daí, fui abrir a 'Caixa de Pandora' e começa a haver toda uma reflexão sobre a coloniza- 
ção, sobre tudo aquilo, que também coloca em causa o meu avô: "OK, o que é que o herói aprendeu no meio disto tudo?" Ele faz o que faz, todo este percurso, a sua jornada, a jornada do herói. Há uma aprendizagem, sendo que este é um filme de comingof-age, de passagem à idade adulta, ele é um garoto, um miúdo que começa criança e termina adulto. $O$ que é que este miúdo aprendeu? Eu olho para o meu avô e penso: "O que é que o meu avô aprendeu?" E olho para a história da minha família e percebo que não aprendeu porra nenhuma em relação a esta viagem! É esta a reflexão que começa a ser feita, é aí que começo a entender: não, não quero contar a história do meu avô, porque o meu avô chega ao final e comete exatamente os mesmos erros. Ele não aprende, passa para o lado do colonizador e volta a repetir tudo, como se nada se tivesse passado. Então, não é a história do meu avô que quero contar. Mais tarde, quando digo numa entrevista que este filme é quase uma redenção por ter nascido num família de colonizadores, isto caiu muito mal na minha família. Mas é verdade, porque é uma forma de eu me colocar no Mundo e dizer "sim, eu venho deste lugar, eu ainda nasci numa colónia", o que é uma coisa completamente absurda de se dizer. Eu sou fruto da colónia. Eu venho desse lugar, mas eu não sou esse lugar, tenho outra visão do Mundo e é esta a minha visão do Mundo. Foi isto, de facto, o que aconteceu. A partir do momento em que uma pessoa começa a querer contar os factos há uma grande responsabilidade. Ainda mais sendo eu europeu, branco, a querer falar de África, aumenta ainda mais a minha responsabilidade e a forma como o vou fazer. E ainda mais quando ponho uma aldeia de mulheres negras 
que tomam protagonismo no filme... Quem sou eu, um homem branco, para falar de mulheres negras e dar-lhes protagonismo? Eu ponho-me num lugar de muita exposição, tenho de ter muita sensibilidade e muita inteligência na forma como o vou fazer. Não posso abordar um tema destes de forma leviana, de forma superficial. O filme é claro nas suas intenções, mas não sei se o consigo porque é muito difícil: continuo a ser europeu, branco, homem. O filme começa com uma visão super eurocêntrica de África, que é o Zacarias, que é a viagem dele, e há um momento em que África toma conta do filme. E depois a questão: que África é esta?

Ao Público, à jornalista Joana Gorjão Henriques, afirmou que "o império colonial poderoso só existiu aos ombros daqueles negros que foram reduzidos à função animal". Disse também: "Andámos à procura do ponto de vista africano sobre o que se tinha passado." Conseguiu encontrar esse "ponto de vista africano"?

Ah, com certeza que não. Andei à procura, mas é muito difícil colocarmo-nos no lugar do outro. Eu não tenho essa vivência, não venho desse lugar. Por mais que intelectualize, por melhores que sejam as minhas intenções, nunca irei chegar lá. Há a questão da viagem e da selva - e o filme tem muito de Conrad e à medida que entramos na selva e a selva aqui é uma entidade que nos leva à loucura, esta relação entre a selvajaria e a loucura do homem ocidental, o homem que se perde... O próprio Conrad tem um visão super eurocêntrica e racista, e o filme baseia-se na sua estrutura, no seu conceito. Então, dentro dessa nar- 
rativa, o filme tem as suas fragilidades, mas eu assumo-as e vou em frente com elas, não as pretendo esconder, assumo-as. Mas, mesmo assim, tento dar aqui um contraponto desta África. Eu e a Fernanda fizemos muitas viagens, mais de 5.000 quilómetros em Moçambique, fizemos 500 mil entrevistas em Moçambique, muita pesquisa, tentámos ir a fundo nestas questões e encontrar esse lado que é personificado na aldeia das mulheres, que tomam o protagonismo. E aqui, claramente, há um momento em que eu dou, ou que tento dar, o protagonismo a estas muIheres, a esta África que é representada nestas mulheres. Mas é uma visão romanceada, tenho conciência disso. Acaba por ser a minha visão, acaba por ser romanceada. Mas acho que há aqui uma liberdade ficcional e criativa para o fazer. O que é certo é que o filme tem o seu impacto, porque apresenta uma perspetiva na qual as pessoas nunca pensaram.

\section{"Acho que andamos todos muito ocupados em sobrevi- ver, para termos tempo para fazer grandes reflexões, para criar coisas mais estruturadas e questionar mais"}

Um tema que teremos necessariamente de abordar nesta conversa é a sua visão da Cultura em Portugal. Considera que existe engajamento político a este nível?

Acho que a Cultura nunca foi olhada em Portugal com um olhar político, suficientemente forte e interessado em tornar a cultura um dos pilares da nossa identidade. Acho que sempre foi vista como um parente pobre, um "tem que ser". Temos de dar ali um dinheiro, temos de aturar artistas, uns chatos, só pedem, 
pedem e nunca estão satisfeitos. E é isso. Acho que a Cultura em Portugal sempre foi olhada pelos políticos como uma chatice, uns tipos chatos que ficam a pedinchar e que não largam o cangote. Esta ministra, em particular, é a representação desse estado de ver as coisas. A Cultura devia ser algo importante e um dos pilares da nossa identidade. Como os franceses sabem fazer. Os franceses são muito bons a defender a sua Cultura, que tem uma importância no Mundo muito maior do que se calhar tem na realidade. Mas eles sabem defender a sua Cultura. Estive em Moçambique no Centro Cultural Francês e é muito mais espetacular do que o Centro Camões. E estamos em Maputo, não devia ser assim... Os franceses sabem como valorizar a sua Cultura, pagam aos artistas com dignidade. E isto leva-nos a outra questão: há uma coisa que é subjacente à atividade artística que é a precariedade. Por exemplo, se eu não tivesse a publicidade para me alimentar, estava tramado. E uma das minhas preocupações, hoje em dia, é: como encontrar este equilíbrio? Como é que consigo sobreviver, pagar a escola dos meus filhos e ter uma vida digna, dedicando-me mais ao cinema e menos à publicidade? E é uma conta difícil de fechar. Sei que não somos um país rico, mas não era preciso muito. Dar uma vida digna aos criadores artísticos não era assim tão pesado. De facto, um artista precisa de viver enquanto cria, enquanto pensa, enquanto faz a sua reflexão sobre o Mundo e sobre as coisas. Mas isso não nos é permitido ou morremos de fome. Andamos aqui na corrida e na angústia de pagar as contas e, ao mesmo tempo, a refletir e a tentar fazer obras de arte. E, de facto, ou temos uma herança de família, ou caímos nas graças e somos os artistas do 
regime - e há muitos - ou é muito difícil. As pessoas esquecem-se que somos nós que criamos a identidade de um país para as futuras memórias, sem nós é o vazio. E isto não tem nada a ver com ser "subsídio dependente", tem a ver com uma coisa muito maior. A arte sempre viveu de mecenas, em toda sua a História. Porque é o Estado não há de ser esse mecenas? Proporcionar a quem quer viver dessa reflexão e da arte uma vida minimamente digna?

O João falou agora em artistas e em precariedade. Assumindo
que o círculo do cinema (como o nomeou nesta conversa) também inclui jornalistas culturais - muitos deles também precários - podemos pensar numa espécie de jogo de favores em que "ganham" sempre os mesmos?

É certo que é difícil entrar num circuito que é muito fechado, mesmo muito fechado. É preciso cair na graça dos "mesmos", se queremos avançar e sermos bem vistos enquanto artistas. Mas, francamente, o que sinto é que andamos todos em modo de sobrevivência. Acho que ninguém tem vidas fáceis, acho que a vida é cada vez mais difícil para toda a gente. Andamos todos muito ocupados em sobreviver, para termos tempo para fazer grandes reflexões, para criar coisas mais estruturadas e questionar mais. Isso reflete-se em todas as áreas e no jornalismo cultural também se reflete. Acho que a maior parte é um bocado "picar o ponto" e pôr as coisas a andar, porque é preciso... Há algumas pessoas que eu sigo, que escrevem na imprensa e que admiro muito, que têm essa independência, como o Vítor Belanciano, que é alguém que escreve tanto sobre música como cinema ou outros assuntos, e eu identifico ali um questionamento e uma independência que acho importante. 
Então, quando pensa em jornalismo cultural pensa essencialmente em imprensa?

Sim. Mas devo dizer-Ihe que a maior parte das entrevistas que me fizeram eram transcrições dos press release que a produtora divulgou, os jornalistas faziam-me as perguntas que vinham nos press release. Depois, quando eu lia o artigo - e isso foi o que senti em relação ao Mosquito - não lia uma crítica, mas uma descrição do filme. Faltava a crítica, a reflexão. Por isso é que digo que andamos demasiado ocupados para sobreviver para ter tempo para isso. E, sim, vou sempre mais para a imprensa, não vejo programas de televisão, pelo menos de informação, mas interessava-me ouvir poadcasts de cultura interessantes. No Brasil, é um coisa que há muito...

Confesso que sempre que penso no Brasil, penso no fenómeno Bolsonaro e na adesão significativa às ideias que defende. Como é que o João, um homem que viveu alguns anos em São Paulo, olha para fenómenos como os populismos e a ascensão de partidos extremistas ao poder? 0 que podemos fazer, enquanto cidadãos com responsabilidades sociais, para combater situações de clara desumanidade e retrocesso civilizacional?

É horrível ao que estamos a assistir. Nunca pensei na minha idade adulta, estar a viver isto. Eu sei lá. Há uma sensação de impotência tão grande que nos assiste, porque é claramente aceitar a "banalização do mal". Isso foi uma coisa que me fez muita impressão no Brasil, quando o Bolsonaro ganhou. No dia após as eleições, tive a certeza que ia voltar para Portugal, não ia conseguir viver num Brasil governado por um psicopata daqueles. 
Nem era só a questão de ser governado por um psicopata, era a questão de haver uma maioria de pessoas que tinham votado nesse psicopata, que o tinham posto no poder. E, no dia a seguir às eleições, andar na rua, olhar para as pessoas e pensar: "Esta pessoa pode ter votado nele... Como é que esta pessoa que é tão simpática e tão civilizada no trato foi capaz de votar naquele personagem?" Não é que essa pessoa seja fascista, conscientemente. Mas há aqui uma alienação, uma falta de empatia, uma grande questão de incapacidade de se colocar no lugar do outro. Um fulano que dizia que matava e que esfolava, que preferia que o filho fosse morto a ser gay, que gozava com o negro ou dizia que o índio não era gente... Mais uma vez, reforço: acho que vivemos num mundo em que estamos tão preocupados em sobreviver que não temos tempo para refletir, para nos aculturarmos, desenvolvermos um pensamento crítico ou um pensamento político...

\section{O que pode ser desastroso.}

É desastroso, completamente. É a tal "banalização do mal", não é? Não que as pessoas sejam psicopatas, mas são capazes de votar num psicopata. E ficar indiferentes ao genocídio dos índios, como está a acontecer... é isso que é assustador. Vivemos numa era em que a verdade já não tem valor, o que interessa é aquilo que nos interessa ouvir, o que queremos ouvir... Por isso é tão importante haver filmes que tragam as tais verdades incómodas, que nos façam pensar e nos façam refletir, nos façam sair desse lugar de nada. É horrível, estamos sempre a dedilhar em nada. E depois deparamo-nos com a desinformação, com as 
falsas verdades... E como damos a volta a isto? Como voltamos a criar gerações empáticas? Acho que a coisa mais importante que temos de desenvolver é a empatia, é o valor mais importante para não cairmos nisso. $E$ isso vem com a educação e com a cultura, não há outra forma. É aí que está o investimento para criarmos gerações mais bem preparadas e informadas, principalmente preparadas para pensar no próximo. É isso. 